MAKING SENSE OF SOCIAL WORK 
Also by Michael Preston-Shoot

CONTRACTS IN SOCIAL WORK (with John Corden) EFFECTIVE GROUPWORK 


\title{
Making Sense of Social Work
}

Psychodynamics, Systems and Practice

Michael Preston-Shoot

\author{
and \\ Dick Agass
}

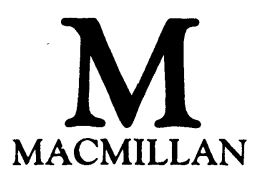


All rights reserved. No reproduction, copy or transmission of this publication may be made without written permission.

No paragraph of this publication may be reproduced, copied or transmitted save with written permission or in accordance with the provisions of the Copyright, Designs and Patents Act 1988, or under the terms of any licence permitting limited copying issued by the Copyright Licensing Agency, 33-4 Alfred Place, London WC1E 7DP.

Any person who does any unauthorised act in relation to this publication may be liable to criminal prosecution and civil claims for damages.

First published 1990

Published by

MACMILLAN EDUCATION LTD

Houndmills, Basingstoke, Hampshire RG21 2XS

and London

Companies and representatives

throughout the world

British Library Cataloguing in Publication Data

Preston-Shoot, Michael, 1951-

Making sense of social work : psychodynamics, systems and practice.

1. Welfare work. Theories

I. Title II. Agass, Dick

361.301

ISBN 978-0-333-49303-8 ISBN 978-1-349-21040-4 (eBook)

DOI 10.1007/978-1-349-21040-4 


\section{Contents}

List of figures vi

Preface vii

Introduction: concerns, curiosity and visions 1

1. Defining the theory: psychodynamics 17

2. Defining the theory: a systems approach 43

3. Psychodynamics and systems: towards a working synthesis for the person-in-situation 62

4. Criticisms, myths and parodies 83

5. Social work and society: downward spirals and doublebinds? 104

6. Making sense of social work tasks 129

7. Supervision, consultation and individual and organisational tangles 162

Postscript: openings into closed systems 191

References $\quad 195$

$\begin{array}{ll}\text { Index } & 210\end{array}$ 


\section{List of figures}

5.1 The downward spiral 109

5.2 A vicious circle in social work 116

6.1 Triangles 152

6.2 Circular reinforcement 154

7.1 Pitfalls in client-social worker interactions 173

$\begin{array}{ll}\text { P.1 A closed system } & 192\end{array}$ 


\section{Preface}

Our initial attempts to achieve a working synthesis in practice between psychodynamic and systems theories were shared with other members of Leeds Family Therapy and Research Centre (Leeds University): Peter Stratton, Gill Tagg, Helga Hanks and Dorothy Heard. From the team we learned a great deal and many of our ideas were worked out in common with them.

Dr Ronald Markillie has been a consistently encouraging teacher and supervisor. Vic Sedlak and Mary Twyman from the Society of Psychoanalytical Psychotherapists have led thought-provoking seminars in Leeds for the past three years. Brian Sidey, Iain Dallas (Bradford Social Services) and Don Wright (Leeds Social Services) have been challenging and helpful colleagues and friends. Suzy Braye (School of Social Work, University of Manchester) read the manuscript and provided welcome support, critical comments and illumination. Alison Cummings and David Hughes, Fiona, Sean and Rachel Agass, and Kay Barella all provided personal support whilst we completed our project.

Jean Ashton, Ruth Carter and Ursula Miley helped to type the manuscript.

We are grateful to them all.

MICHAEL PRESTON-SHOOT

DICK AGASS 